\title{
Estabilidad del estado pasivo del acero en morteros de ceniza volante activada
}

\section{Steel passive state stability in activated fly ash mortars}

\author{
A. Fernández-Jiménez ${ }^{(*)}$, J. M. Miranda(**), J. A. González(***), A. Palomo(*)
}

Recepción/Received: 22-VII-09

Aceptación/Accepted: 09-IV-10

Publicado online/Online publishing: 26-IV-10

\section{RESUMEN}

En el presente trabajo se estudia el comportamiento del acero estructural embebido en morteros de cemento Pórtland (OPC) y de cenizas volantes activadas con $\mathrm{NaOH}$ y una mezcla de $\mathrm{NaOH}$ y waterglass, en ausencia y en presencia de un $2 \%$ de $\mathrm{Cl}^{-}\left(\mathrm{CaCl}_{2}\right)$. Se determinó la evolución del potencial de corrosión $\left(E_{\text {corr }}\right)$, la resistencia de polarización lineal $\left(R_{p}\right)$ y la intensidad de corrosión ( $\mathrm{i}_{\text {corr }}$ ), variando las condiciones ambientales (90 días al 95\% de humedad relativa (HR) -30 días $a \approx 30 \%$ HR- 760 días a $\approx 95 \%$ HR). En ausencia de $\mathrm{Cl}^{-}$los morteros de cenizas volantes activadas pueden pasivar los refuerzos de acero, si bien la estabilidad del estado pasivo ante cambios en las condiciones ambientales parece mostrar una fuerte dependencia de la solución activadora empleada. En presencia de un $2 \%$ de $\mathrm{Cl}^{-}$los aceros se corroen mostrando en comportamiento similar al observado en morteros en base OPC.

Palabras clave: corrosión, cenizas volantes, activación alcalina, morteros, resistencias mecánicas.

\section{SUMMARY}

The present study explores the behaviour of structural steel embedded in Portland cement (OPC) mortars and $\mathrm{NaOH}$ - and $\mathrm{NaOH}+$ waterglass-activated fly ash, in the presence and absence of $2 \% \mathrm{Cl}^{-}\left(\mathrm{CaCl}_{2}\right)$. Variations were determined in the corrosion potential ( $E_{\text {corr }}$ ), linear polarization resistance $\left(R_{p}\right)$ and corrosion current density $\left(i_{\text {corr }}\right)$ under different environmental conditions (90 days at $95 \%$ relative humidity $(R H), 30$ days at $\approx$ $30 \% R H, 760$ days at $\approx 95 \% R H)$. In the absence of $\mathrm{Cl}^{-}$, fly ash mortars were able to passivate steel reinforcement, although the stability of the passive state in changing environmental conditions was found to depend heavily on the activating solution used. Steel corrosion in the presence of $2 \% \mathrm{Cl}^{-}$was observed to be similar to the corrosion reported for the material in OPC mortars.

Keywords: corrosion, fly ash, alkali activation, mortars, mechanical strength.

(*) Instituto Eduardo Torroja (CSIC) (Madrid, España).

(**) Universidad Autónoma de San Luis de Potosí (San Luis de Potosí, México).

(***) Centro Nacional de Investigaciones Metalúrgicas National (CSIC) (Madrid, España). 


\section{INTRODUCCIÓN}

El sector de la construcción moviliza, aproximadamente, un $10 \%$ de la economía mundial y consume un $40 \%$ de la energía (1), siendo el hormigón, en masa y armado, el material de construcción que supera en tonelaje al resto de materiales considerados conjuntamente. El gran consumo de energía que exige la elaboración del cemento Pórtland (OPC), explica el elevado impacto ambiental atribuible a su fabricación, hasta el punto de considerar a la industria cementera responsable de la emisión a la atmósfera de un 6-7\% de los gases con efecto invernadero (2). Ésta es una de las principales razones que motiva la búsqueda de soluciones tales como desarrollar materiales cementantes alternativos al cemento Pórtland (3-7). Una posible alternativa es incrementar el contenido de las adiciones que actualmente se permite incorporar al cemento Pórtland, es decir, fabricar cementos con contenidos en clínker inferiores al 30\% (8-9) o incluso la fabricación de cementos exentos de OPC, como los morteros y/o hormigones elaborados por activación alcalina de cenizas volantes $(3,10-12)$.

En trabajos previos (13) se ha visto que la adición de cenizas volantes causa una disminución en la permeabilidad al cloruro en hormigones de cemento Pórtland hasta un $50 \%$ de reemplazamiento. Sin embargo el valor umbral de cloruros, o cantidad requerida para iniciar un proceso corrosivo, disminuye cuando se incrementa el contenido de cenizas volantes (14). Trabajos recientes apuntan a que las cenizas volantes pueden acelerar la corrosión de los refuerzos de acero debido a la presencia de in-quemados de C y S (15-16). No obstante trabajos donde se adopta diferentes técnicas de activación de mezclas cemento Pórtland/cenizas volantes muestran que la presencia de cenizas volantes en estos casos puede mejorar la resistencia del hormigón a la corrosión (17-18). Así Saraswathy et al. (17) comparando resultados obtenidos para hormigones de cemento Pórtland y hormigones con un reemplazamiento entre el $10-40 \%$ de ceniza volante, concluye que el acero embebido en las mezclas de OPC con ceniza volante no activada sufre severa corrosión, mientras que hormigones de OPC conteniendo ceniza volante activada mejoran la resistencia a la corrosión hasta un máximo de 25 veces. Por otro lado algunos de los autores de este trabajo han podido contrastar que efectivamente mezclas de cemento Pórtland y ceniza volante activada (18), pueden presentar un comportamiento aceptable frente a la corrosión de las armaduras embebidas en su interior, siempre y cuando se controlen ciertos parámetros importantes en el proceso de activación, como es el procesado inicial del material y el tipo de activador alcalino empleado.

En un trabajo previo publicado en 2005 (19) ya se pudo comprobar que en un periodo relativamente corto de

\section{INTRODUCTION}

The construction industry uses more bulk and reinforced concrete, by tonnage, than all other building materials combined. The significance of this statistic lies in the importance of the industry itself, which accounts for approximately $10 \%$ of the world economy and $40 \%$ of the energy consumed (1). The environmental impact attributable to the manufacture of Portland cement is largely due to the energy-intensive processes involved: indeed, the cement industry is regarded to be responsible for $6-7 \%$ of all the greenhouse gases emitted world-wide (2). This is one of the main reasons behind the pursuit of solutions involving the development of alternative cementitious materials (3-7). One possible alternative is to increase the percentage of additions presently allowable in Portland cement: in other words, to manufacture cements with a clinker content of under $30 \%$ (8-9) or even 0 per cent OPC, such as the mortars and concretes made by alkali activating fly ash $(3,10-12)$.

Prior studies (13) showed that fly ash additions at replacement rates of up to $50 \%$ reduced the chloride permeability of Portland cement concrete. The chloride threshold value or amount of ions needed to initiate corrosion is lower at higher fly ash contents, however (14). Recent studies suggest that fly ash may accelerate reinforcing steel corrosion due to the presence of unburnt $C$ and $S$ in the material $(15,16)$. Nonetheless, studies using different activation techniques for Portland cement-fly ash blends show that the presence of the ash in such cases may improve concrete corrosion resistance (17-18). Saraswathy et al. (17), for instance, compared findings for Portland cement concrete to the results for concrete with $10-40 \%$ fly ash replacement rates. They concluded that the steel embedded in OPC-non-activated fly ash blends underwent severe corrosion, while OPC concrete containing activated fly ash raised corrosion resistance by factors of up to 25. Moreover, some of the authors of the present study (18) found that Portland cement-activated fly ash blends may perform acceptably well with respect to embedded reinforcement corrosion, providing certain key activation parameters are controlled, such as initial material processing and the type of activator used.

A prior study published in 2005 (19) showed that in a fairly short period of time (3 months) activated fly ash 
tiempo (3 meses), los morteros de cenizas volantes activadas pasivan a los refuerzos de acero tan rápida y perfectamente como los morteros de cemento Pórtland, propiedad muy importante, puesto que, la causa principal que limita la vida en servicio de las estructuras de hormigón armado (EHA) radica en la corrosión de los refuerzos $(20,21)$. No obstante, el estudio mencionado se extendía a un periodo de tiempo muy limitado, de 90 días y a unas condiciones de exposición invariables, atmósfera de elevada humedad relativa, para detectar inmediatamente la pérdida del estado pasivo, en el caso de que tuviera lugar.

En el presente trabajo se explora la posibilidad de conseguir, con los cementos de cenizas volantes activadas, la inalterabilidad de los refuerzos mediante la pasivación de los mismos, como sucede con los cementos Pórtland. Para ello se lleva a cabo un estudio comparativo entre ambos tipos de materiales como en el trabajo anterior, pero extendiendo el periodo de exposición de 90 días a más de dos años. Durante los primeros 90 días los materiales se mantuvieron en condiciones de elevada humedad relativa, después se pasó a humedad relativa baja $(\approx 30 \%)$ durante 30 días, y a partir de los 120 días hasta final del ensayo (2,5 años) de nuevo se pasó a condiciones atmosféricas de elevada humedad relativa ( $\approx 95 \%$ HR). El objetivo de estos cambios era determinar la estabilidad del estado pasivo de los refuerzos de acero ante cambios atmosféricos, y la dependencia de la cinética de corrosión con el grado de humectación de los materiales de construcción y el tipo de activador alcalino empleado en la preparación de los morteros de ceniza volante activada alcalínamente. Entendiéndose que el acero está en estado pasivo cuando exhibe una reactividad muy pequeña, es decir, presenta una velocidad de corrosión insignificante en medios en los cuales tiene una elevada tendencia termodinámica a corroerse.

\section{EXPERIMENTAL}

\subsection{Materiales}

La presente investigación se llevó a cabo utilizando un cemento Pórtland comercial tipo I y una ceniza volante procedente de una central térmica del norte de España. La composición química y superficie específica de ambos materiales se detalla en la Tabla 1. Con estos materiales se prepararon morteros de cemento Pórtland y de ceniza activada alcalínamente utilizando arena normalizada de granulometría constante y con un contenido en sílice superior al $90 \%$, según se especifica en la Tabla 2. Como activadores se utilizó una disolución $(\mathrm{N})$ de $\mathrm{NaOH} 8 \mathrm{M}$, y una disolución (NW) preparada con la mezcla de un $85 \%$ de $\mathrm{NaOH} 12,5 \mathrm{M}$, más un $15 \%$ de waterglass $(27 \%$ de $\mathrm{SiO}_{2}, 8,2 \%$ de $\mathrm{Na}_{2} \mathrm{O}$ y $64,8 \%$ de $\mathrm{H}_{2} \mathrm{O}$ ). mortars passivate steel reinforcement as rapidly and effectively as Portland cement mortars. This is a very important property, for reinforcing steel corrosion is the major factor affecting the service life of reinforced concrete structures $(20,21)$. That study was conducted over a very short period of time (90 days), however, and under exposure conditions in which relative humidity was kept consistently high to be able to immediately detect any decline in passivity.

The present study aimed to determine whether activated fly ash cements can induce reinforcement inalterability through passivation as effectively as Portland cements. As in the prior study, experiments were conducted to compare the performance of the two types of materials, but here exposure was extended from 90 days to over two years. In the first 90 days the materials were stored in high relative humidity conditions, in the following 30 in low $H R(\approx 30 \%)$ and from the $120^{\text {th }}$ day through the end of the trial period (2.5 years), again at high relative humidity $(\approx 95 \%)$. The purpose of changing conditions was to determine the passive state stability of steel reinforcement bars when exposed to atmospheric changes, as well as the dependence of corrosion kinetics on the moisture content of construction materials and the type of alkali activator used to prepare alkaliactivated fly ash mortars. Steel was understood to be in a passive state when it exhibited very low reactivity, i.e., a negligible corrosion rate in media where the thermodynamics further corrosion.

\section{EXPERIMENTAL}

\subsection{Materials}

The present study was conducted with type I commercial Portland cement and fly ash from a coal-fired steam power plant in northern Spain. The chemical composition and specific surface of these materials are given in Table 1. These materials were used to prepare Portland cement-alkali-activated fly ash mortars using standard sand with a single particle size and a silica content of over $90 \%$ as seen in Table 2. The activators used were an 8-M solution of $\mathrm{NaOH}(\mathrm{N})$ and a solution (NW) prepared with an $85 / 15 \%$ mix of $12.5-\mathrm{M} \mathrm{NaOH}$ and waterglass (27\% $\mathrm{SiO}_{2}, 8.2 \% \mathrm{Na}_{2} \mathrm{O}$ and $64.8 \% \mathrm{H}_{2} \mathrm{O}$ ). 
Los tres tipos de mortero se prepararon sin cloruros y con la adición de un $2 \%$ de $\mathrm{Cl}^{-}$en relación al peso de conglomerante. $\mathrm{El} \mathrm{CaCl}_{2}$ se empleó como fuente de $\mathrm{Cl}^{-}$ resultando al final 6 tipos diferentes de materiales, cuya composición se especifica en la Tabla 2.
The three types of mortar were prepared with 0 and $2 \%$ chloride by binder weight. $\mathrm{CaCl}_{2}$ was used as a source of $\mathrm{Cl}$. The composition of the six materials resulting from the above combinations is given in Table 2.

Tabla 1. Composición química (\% en masa) y superficie específica (Blaine $\left(\mathrm{m}^{2} / \mathrm{kg}\right)$ del cemento y la ceniza volante). Table 1. Cement and fly ash chemical composition (\% in mass) and Specific Surface (Blaine $\left(\mathrm{m}^{2} / \mathrm{kg}\right)$.

\begin{tabular}{|c|c|c|c|c|c|c|c|c|c|c|c|}
\hline & L.o. $1^{\circ}$ & $\mathbf{I R}^{\mathrm{b}}$ & $\mathrm{SiO}_{2}$ & $\mathrm{Al}_{2} \mathrm{O}_{3}$ & $\mathrm{Fe}_{2} \mathrm{O}_{3}$ & $\mathrm{CaO}$ & $\mathrm{MgO}$ & $\mathrm{SO}_{3}$ & $\mathrm{~K}_{2} \mathrm{O}$ & $\mathrm{Na}_{2} \mathrm{O}$ & Sp.surf \\
\hline CEM I & 1.48 & 0.55 & 19.92 & 6.44 & 1.16 & 63.28 & 0.63 & 1.09 & - & - & 545 \\
\hline Ceniza / Fly ash & 1.80 & 0.40 & 51.51 & 27.47 & 7.23 & 4.39 & 1.86 & 0.15 & 3.46 & 0.70 & 360 \\
\hline
\end{tabular}

$a=$ Pérdida por calcinación / Loss on Ignition. $b=$ Residuo insoluble / Insoluble residue.

Tabla 2. Composición de los morteros. Table 2. Mortar composition.

\begin{tabular}{|c|c|c|c|c|c|}
\hline Mortero / Mortar & $\begin{array}{l}\text { Cloruros / } \\
\text { Chloride }\end{array}$ & Cemento (B) / Binder (B) & $\begin{array}{c}\text { Arena / B ratio / } \\
\text { Sand / B ratio }\end{array}$ & Líquido (L) / Type of liquid (L) & L/B1 / ratio \\
\hline 1 & - & $100 \%$ OPC I (52.5) & $3 / 1$ & Agua / Water & 0.55 \\
\hline $2 \mathrm{Cl}-$ & $2 \%\left(\mathrm{CaCl}_{2}\right)$ & $100 \%$ OPC I (52.5) & $3 / 1$ & Agua / Water & 0.55 \\
\hline 3 & - & $100 \%$ Cenizas volantes / Fly Ash & $2 / 1$ & $2 \mathrm{~N}$ & 0.35 \\
\hline $4 \mathrm{Cl}-$ & $2 \%\left(\mathrm{CaCl}_{2}\right)$ & $100 \%$ Cenizas volantes / Fly Ash & $2 / 1$ & $2 \mathrm{~N}$ & 0.35 \\
\hline 5 & - & $100 \%$ Cenizas volantes / Fly Ash & $2 / 1$ & ${ }^{3} \mathrm{NW}$ & 0.35 \\
\hline $6 \mathrm{Cl}-$ & $2 \%\left(\mathrm{CaCl}_{2}\right)$ & $100 \%$ Cenizas volantes / Fly Ash & $2 / 1$ & ${ }^{3} \mathrm{NW}$ & 0.35 \\
\hline
\end{tabular}

1 = Líquido/material cementante (\% en masa) / Liquid/binder ratio (\% in mass).

${ }^{2} \mathrm{~N}=\mathrm{NaOH} 8 \mathrm{M} ;{ }^{3} \mathrm{NW}=15 \%$ waterglass $+85 \%(12.5 \mathrm{M} \mathrm{NaOH})$.

\subsection{Técnicas de medida}

Para determinar las resistencias mecánicas de los morteros se elaboraron probetas prismáticas de $(4 \times 4 \times 16 \mathrm{~cm})$ en las relaciones arena / material cementante indicadas en la Tabla 2 y, todos los morteros se curaron inicialmente 20 horas a $50^{\circ} \mathrm{C}$ en atmósfera saturada de humedad. Una vez desmoldados los morteros en base cemento se guardaron en la cámara de curado ( $22{ }^{\circ} \mathrm{C}$, 98\% HR) otras 24 horas, mientras que los morteros en base ceniza se curaron térmicamente otras 20 horas a $85^{\circ} \mathrm{C}$ y elevada HR. Estos morteros fueron ensayados a 2 días según la norma EN 196-1:2005 (22).

Para las medidas de corrosión, se emplearon probetas prismáticas de mortero de $8 \times 5 \times 2,5 \mathrm{~cm}$ similares a las utilizadas en investigaciones previas $(18,19)$. En ellas se embebieron, en posiciones simétricas, dos redondos de acero para armar de 0,6 cm de diámetro, que actuaban como electrodos de trabajo durante las medidas, y un alambre de acero inoxidable de 0,5 cm de diámetro, en posición central que servía como contra-electrodo, refiriendo siempre los potenciales al electrodo saturado de calomelanos (ESC). Sobre los electrodos de trabajo se delimitaron con cinta adhesiva una superficie activa de 10 $\mathrm{cm}^{2}$, aislando la interfase triple acero-mortero-atmósfera para evitar un posible ataque localizado por aireación

\subsection{Measuring techniques}

Mortar mechanical strength was determined on 4-cm square by $16-\mathrm{cm}$ deep prismatic specimens prepared with the sand / binder ratios specified in Table 2. All the mortars were initially cured for 20 hours at $50{ }^{\circ} \mathrm{C}$ in a very high humidity atmosphere. After removal from the moulds the cement-based mortars were stored in a curing chamber $\left(22^{\circ} \mathrm{C}, 98 \% \mathrm{RH}\right)$ for a further 24 hours, while the fly ash-based specimens were cured thermally at $85{ }^{\circ} \mathrm{C}$ at a high $\mathrm{RH}$ for 20 hours. The 2-day mortars were tested as specified in European standard EN 196-1:2005 (22).

Prismatic mortar specimens measuring $8 \times 5 \times 2.5 \mathrm{~cm}$, similar to the samples used in prior studies $(18,19)$, were prepared for the corrosion measurements. These specimens were reinforced with two symmetrically embedded, $0.6 \mathrm{~cm}$ round steel bars that worked as test electrodes during measurement readings, and an $0.5 \mathrm{~cm}$ diameter stainless steel wire in a central position that served as the auxiliary electrode. The corrosion potential values were referred to the saturated calomel electrode (SCE). An active area measuring $10 \mathrm{~cm}^{2}$ was delimited on the test electrodes with adhesive tape to insulate the triple steel-mortar-air interface and prevent possible local attacks due to differential aeration $(18,19)$. The 
diferencial $(18,19)$. El contacto eléctrico del contra-electrodo con las probetas de mortero se facilitó durante las medidas interponiendo entre ambos una esponja humedecida. Cada medida se realizó siempre por triplicado.

El comportamiento de los electrodos de acero a lo largo del periodo de exposición se controló determinando su potencial de corrosión ( $\mathrm{E}_{\text {corr }}$ ); la velocidad de corrosión a partir de medidas de la resistencia de polarización $\left(R_{p}\right)$ siguiendo las indicaciones de la norma ASTM C876-09 (23), que permitían la estimación de las densidades de corriente de corrosión ( $\mathrm{i}_{\text {corr }}$ ) recurriendo a la ecuación de Stern y Geary (24) y, por contraste de las estimaciones electroquímicas con la sintomatología visual de la corrosión, una vez finalizados los ensayos y rotas las probetas de mortero. Los $\mathrm{E}_{\text {corr }}$ proporcionan orientaciones valiosas, aunque exclusivamente cualitativas, sobre el estado activo o pasivo de los refuerzos, mientras que las $\mathrm{i}_{\text {corr }}$ ofrecen una información cuantitativa sobre el proceso de deterioro de los refuerzos. La sintomatología visual ofrece una estimación directa de la corrosión que permite apreciar la fiabilidad de las estimaciones electroquímicas indirectas si bien, hay que reconocerlo, sería más convincente haber previsto una determinación gravimétrica cuantitativa.

Para analizar su comportamiento frente a la corrosión, las probetas se mantuvieron primero durante 90 días en un ambiente de elevada humedad relativa $(\approx 95 \%)$, para favorecer al máximo los procesos de deterioro, en el caso de que se destruyera la pasividad por efecto de los cloruros añadidos. Posteriormente se trasladaron a la atmósfera seca del laboratorio con humedades relativas fluctuando en torno al $30 \%$, condiciones en las que se mantuvieron desde los 90 a los 120 días, retornándolas a la atmósfera húmeda de $\approx 95 \%$ HR hasta finalizar la exposición a los 2,5 años de iniciados los ensayos.

Como análisis complementario se determinó la porosidad de las muestras al cabo de 2,5 años utilizando Porosimetría de Intrusión de Mercurio (MIP) (muestras sin adición de $\mathrm{Cl}^{-}$). El equipo utilizado fue un Autopore II 92220 de Micrometrics Instruments.

\section{RESULTADOS Y DISCUSIÓN}

En la Figura 1, se reproducen los valores de la resistencia a la compresión a las 48 horas de amasado para los tres tipos de mortero, sin y con adiciones de cloruros (tres probetas prismáticas de mortero fueron ensayadas para cada matriz). Todos los materiales alcanzan niveles altos de resistencia en tiempos cortos, lo que se debe, en gran parte, al curado térmico descrito en la parte experimental. No obstante se observa que mientras los morteros de ceniza volante activados con la disolución $\mathrm{NaOH}$ electrical connection between the counter electrode and the mortar specimens was enhanced by placing a moist sponge between the two during measurement readings. All measurements were taken three times.

Three methods were used to monitor steel electrode behaviour during exposure: frequent determination of the corrosion potential $\left(E_{c o r r}\right)$; polarization resistance $\left(R_{p}\right)$ readings to find the corrosion rate pursuant to U.S. standard ASTM C876-09 (23) from which to estimate corrosion current densities ( $\left.i_{\text {corr }}\right)$ using the Stern and Geary equation (24); and verification of the electrochemical estimates with visual signs of corrosion at the end of the trial when the mortar specimens were split open. $E_{\text {corr }}$ readings provide valuable, albeit solely qualitative, information on the active or passive state of the reinforcement, whereas $i_{\text {corr }}$ measurements furnish quantitative data on rebar deterioration. While visual symptoms, which afford a direct estimate of corrosion, are useful for judging the reliability of the indirect electrochemical estimates, quantitative gravimetric analysis would, naturally, have yielded more accurate findings.

For the first 90 days, corrosion performance was analyzed by storing the specimens in a high relative humidity $(\approx 95 \%)$ environment, which would favour deterioration if passivity was destroyed by the chloride ions added to the mix. From the the 90th to the $120^{\text {th }}$ day samples were placed in a dry laboratory atmosphere where the relative humidity hovered around $30 \%$. They were subsequently returned to a humid atmosphere with $\mathrm{RH} 95 \%$ for the remainder of the 2.5 year test period.

Sample porosity after 2.5 years was also determined for the samples with $0 \%$ chlorides, using mercury intrusion porosimetry (MIP) on a Micrometrics Instruments Autopore II 92220 analyzer.

\section{RESULTS AND DISCUSSION}

Figure 1 shows the 48 hour compressive strength values for the three types of mortar, with and without chlorides (three prismatic mortar specimens were tested for each mix). All the materials reached high early strength values, due largely to the thermal curing described in the experimental section of this paper. Nonetheless, while the mortars containing fly ash activated with 8-M NaOH exhibited strength similar to Portland cement (with values ranging from 30 to $40 \mathrm{MPa}$ ), the mortars made 
8M presentan un comportamiento resistente muy similar al del cemento Pórtland (con valores comprendidos entre los 30-40 MPa), los morteros de ceniza volante activados con la disolución NW presentan, tanto en ausencia como en presencia de $\mathrm{Cl}^{-}$, unas resistencias mecánicas claramente superiores. En trabajos previos (25-27) se ha comprobado que efectivamente la presencia en la disolución de una pequeña cantidad de sílice soluble incrementa notablemente las resistencias de estos materiales. Este hecho, como se verá más adelante, parece guardar una buena correlación con el mejor comportamiento de protección frente a la corrosión observado en este mortero. with fly ash activated with the NW solution had clearly higher mechanical strength, both in the presence and absence of Cl. Prior studies (25-27) showed that the presence in the solution of a small amount of soluble silica enhanced the strength of these materials substantially. This finding, as discussed below, appeared to be closely correlated to the more effective corrosion protection observed in this mortar.

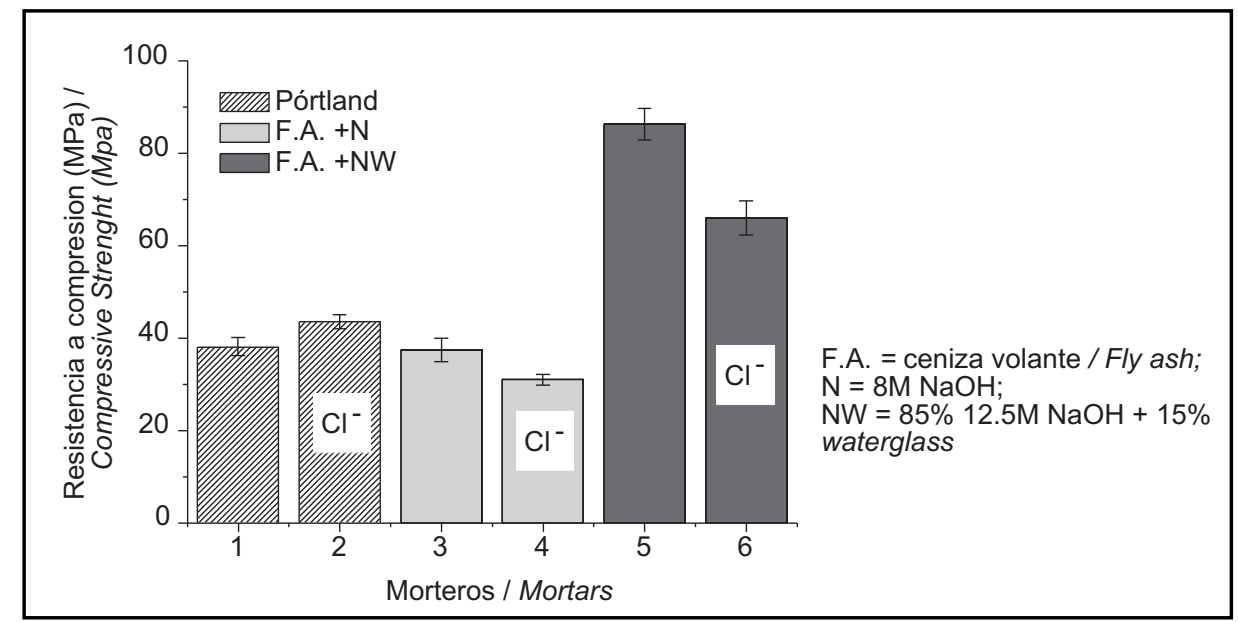

Figura 1. Resistencia a la compresión de los diferentes morteros a las 48 horas de su fabricación.

Figure 1. Compressive strength of the different types of mortar, 48 hours after manufacture.

En la Figura 2 ( $a$, b y c) se muestra la evolución de los $\mathrm{E}_{\text {corr }}$ con el tiempo en ausencia y presencia de las adiciones de cloruros. Los resultados fueron interpretados de acuerdo a lo establecido por la norma ASTM C 876-09 (23) con las correcciones adecuadas en función del electrodo de referencia empleado (17). Así, potenciales de corrosión más positivos que el potencial umbral de -275 $\mathrm{mV}$ frente al electrodo saturado de calomelanos (ESC) indican baja probabilidad de corrosión de las armaduras en la zona inspeccionada. Potenciales de corrosión inferiores (más negativos) indican una probabilidad superior al $90 \%$ de que ocurra corrosión en estado activo.

En ausencia de $\mathrm{Cl}^{-}$, inicialmente $(\mathrm{HR} \approx 95 \%)$ todos lo morteros estudiados presentan una comportamiento homogéneo con una muy baja probabilidad de corrosión. Los cambios ambientales afectan a este comportamiento especialmente para los morteros de ceniza volante activada con la disolución de N. En este caso el paso de humedad-secado y de nuevo humedad hace que aumente hasta un $90 \%$ la probabilidad de corrosión. Para el caso de los morteros de ceniza activados con la disolución NW, también aumenta la probabilidad pero no de forma tan acusada al pasar a una zona de incertidumbre (ver Figura 2).
Figure 2 ( $a, b$ and $c)$ show the variation in $E_{\text {corr }}$ values with time in the presence and absence of chlorides. The results were interpreted as specified in standard ASTM $C$ 876-09 (23), corrected for the reference electrode used (17). Hence, corrosion potential values that were more positive than the threshold $-275 \mathrm{mV}$ with respect to the saturated calomel electrode (SCE) were interpreted to indicate a low likelihood of reinforcement corrosion in the area inspected. Lower (i.e., more negative) corrosion potential values were regarded to be indicative of a likelihood of active steel corrosion of over $90 \%$.

In the absence of $\mathrm{Cl}$, initially $(\mathrm{RH} \approx 95 \%)$ all the mortars studied behaved in much the same way, with a low probability of corrosion. Environmental changes affected this behaviour, particularly in the $\mathrm{N}$-activated fly ash mortars. In this case the change from moist to dry and back to moist raised the likelihood of corrosion to $90 \%$. The likelihood of corrosion also rose for the NWactivated fly ash mortars, but not as steeply: these values moved, rather, into an area of uncertainty (see Figure 2). 
En presencia de cloruros y en ambientes húmedos se ponen de manifiesto diferencias de 300-400 mV entre los $\mathrm{E}_{\text {corr }}$ de los estados pasivo y activo, correspondiendo a éste los más negativos. En los que respecta a las variaciones del $\mathrm{E}_{\text {corr }}$ correspondiente al estado activo en función del grado de humectación de sus poros, se observa que en los morteros secos se miden $\mathrm{E}_{\text {corr }}$ próximos a $-200 \mathrm{mV}$ y en los húmedos en torno a $-500 \mathrm{mV}$. Ello hace que en ambiente secos los $\mathrm{E}_{\text {corr }}$ entre los estados activo y pasivo se confundan, llegando incluso, en ocasiones, a ser más negativos los correspondientes al estado pasivo, lo cual corrobora el hecho de que en ausencia de humedad la corrosión está limitada. Al pasar de nuevo a condiciones de humedad las diferencias entre el estado activo y pasivo se recuperan.
Differences of 300-400 mV were observed between the passive and active state $E_{\text {corr }}$ values in the presence of chlorides and moist environments. The most negative figures were recorded for the active steel. The active state $E_{\text {corr }}$ values were observed to vary depending on pore moisture content, with readings in dry mortars of around $-200 \mathrm{mV}$ and of about $-500 \mathrm{mV}$ in moist mortars. The result was that in dry environments the active and passive state $E_{\text {corr }}$ values overlapped. The fact that some of the values for the passive steel were more negative than for the active steel corroborated the observation that corrosion is less acute in the absence of moisture. With the change back to a moist environment, the gap between the active and passive states re-appeared.
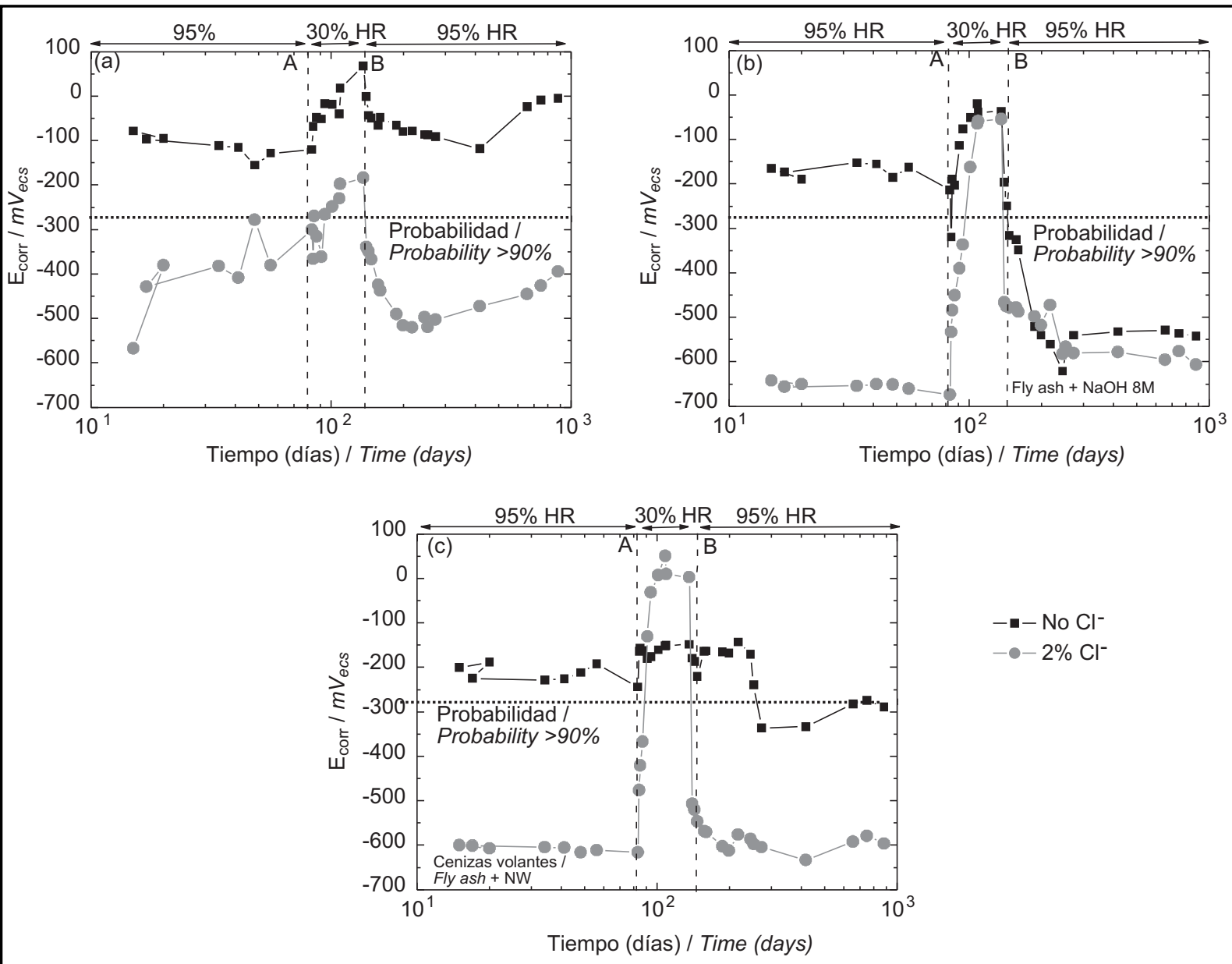

$-\mathbf{- n o ~} \mathrm{Cl}^{-}$

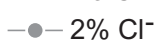

Figura 2. $\mathrm{E}_{\mathrm{corr}}$ en función del tiempo; (a) Mortero arena /cemento $=3 / 1$; (b) mortero arena/ cenizas volantes=2/1 activadas con una solución de $\mathrm{NaOH} 8 \mathrm{M}$; (c) mortero arena/cenizas volantes=2/1 activadas con una solución de NW.

Figure 2. $E_{\text {corr }}$ vs time (a) Mortar sand/binder = 3/1; (b) Mortar sand/ fly ash = 2/1 activated with $8 M-N a O H ;(c)$ Mortar sand/fly ash $=2 / 1$ activated with NW.

Para extraer conclusiones de estos datos es necesario tener presente que el $\mathrm{E}_{\mathrm{corr}}$, es un parámetro electroquímico relativamente fácil y rápido de medir, y por tanto uno de los más utilizados en la práctica. Su principal
$E_{\text {corr }}$ is quickly and conveniently measured and for that reason one of the most widely used electrochemical parameters. Its main advantage is that it can reveal the likelihood of active steel corrosion (23, 28-33), providing 
ventaja reside en su capacidad de poner de relieve, la probabilidad de corrosión en estado activo (23, 28-33), siempre que la comparación se realice entre elementos estructurales que mantienen un elevado estado de humectación. Su principal limitación radica en que los $\mathrm{E}_{\text {corr }}$ no sólo pueden cambiar centenares de $\mathrm{mV}$ con la transición entre los estados pasivo y activo, sino también con el grado de humectación de los materiales de construcción, comportamiento mucho más acusado en los refuerzos en estado activo que en los que permanecen en el estado pasivo. Tales peculiaridades pueden comprobarse con la simple observación de las Figuras (2a, b y c), especialmente en esta última donde se demuestra que, en ocasiones, los $E_{\text {corr }}$ de los refuerzos pasivos pueden ser más negativos incluso que los de los refuerzos activos sometidos a idénticas condiciones ambientales.

La Figura 3 ( $a$, b y c) muestra la evolución de las $\mathrm{i}_{\text {corr }}$ de los redondos de acero embebidos en el mortero de cemento Pórtland, y en los morteros de ceniza volante activada alcalinamente con las disoluciones $\mathrm{N}$ y NW respectivamente, sin cloruros y con la adición de un $2 \%$ de $\mathrm{Cl}^{-}$. Los puntos A y B indican los valores de tiempo a los cuales se varió las condiciones de humedad relativa a las que estuvieron expuestas las probetas (95\%-30\%-95\% de HR) tal y como se indicó en el apartado experimental.

Los niveles de corrosión pueden ser definidos como (28): $\mathrm{i}_{\text {corr }}<0,1 \mu \mathrm{A} \mathrm{cm}-2$ pasivo; $0,1 \mu \mathrm{A} \mathrm{cm}^{-2}<\mathrm{i}_{\text {corr }}<0,5 \mu \mathrm{A} \mathrm{cm} \mathrm{cm}^{-2}$ corrosión baja; $0,5 \mu \mathrm{A} \mathrm{cm}{ }^{-2}<\mathrm{i}_{\text {corr }}<1,0 \mu \mathrm{A} . \mathrm{cm}^{-2}$ corrosión alta y $\mathrm{i}_{\text {corr }}>1,0 \mu \mathrm{A} \mathrm{cm}{ }^{-2}$ corrosión muy alta. Esta clasificación es muy exhaustiva por ello en el presente trabajo para simplificar la representación gráfica se ha adoptado el criterio sugerido por Andrade et al. (29) dibujándose una línea horizontal en la figuras para valores de $\mathrm{i}_{\text {corr }}$ de 0,2 $\mu \mathrm{A} \mathrm{cm}^{-2}$ valor que se toma como inicio de corrosión activa.

Así, los resultados obtenidos muestran que:

a) En condiciones de elevada humedad relativa la adición de cloruros incrementa en todos los casos la

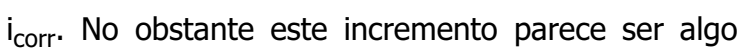
mayor en los morteros de ceniza volante activada alcalinamente donde este valor se multiplica por un factor cercano a 100 .

b) Inicialmente, desde el curado de las probetas a su trasvase desde la atmósfera húmeda al ambiente seco del laboratorio, las $i_{\text {corr }}$ de los estados pasivo y activo se diferencian, en los dos morteros, aproximadamente unos dos órdenes de magnitud, como sucede en el caso del mortero de cemento Pórtland (Figuras $3 a, b$ y c).

c) Sin embargo, a continuación del proceso de secado la nueva humidificación introduce llamativas diferencias entre los dos tipos de morteros de cenizas volantes. En el mortero activado con $\mathrm{NaOH} 8 \mathrm{M}$ las $\mathrm{i}_{\text {corr }}$ de los refuerzos the comparison is made between structural members with a high moisture content. The main drawback is that $E_{c o r r}$ values change by hundreds of $\mathrm{mV}$ not only in the transition between the passive and active state, but also with the moisture content in construction materials. And this behaviour is much more accentuated in reinforcing steel in the active than in the passive state. Such peculiarities are clearly visible in Figures $2 a$ and $b$ and especially in $2 c$ where, on occasion, the $E_{\text {corr }}$ values for the passive steel were even more negative than for the active reinforcement bars subjected to exactly the same environmental conditions.

Figure 3 ( $a, b$ and $c$ ) show the variation in $i_{\text {corr }}$ values in steel rounds embedded in Portland cement and $\mathrm{N}$ - and $\mathrm{NW}$-activated fly ash mortar, with 0 and $2 \% \mathrm{Cl}$. Vertical lines $A$ and $B$ mark the change in the relative humidity to which the specimens were exposed (95\%-30\%-95\% $R H)$, as explained in the experimental section.

Corrosion levels may be defined as (28): $i_{\text {corr }}<0.1 \mu \mathrm{A}$ $\mathrm{cm}^{-2}$ : passive; $0.1 \mu \mathrm{A} \mathrm{cm}^{-2}<i_{\text {corr }}<0.5 \mu \mathrm{A} \mathrm{cm}-2$ : low; $0.5 \mu \mathrm{A} \mathrm{cm}^{-2}<i_{\text {corr }}<1.0 \mu \mathrm{A} \mathrm{cm}-2$ : high and $i_{\text {corr }}>1.0$ $\mu A \mathrm{~cm}^{-2}$ : very high. As this classification is fairly exhaustive, in the present study the criterion suggested by Andrade et al. (29) was adopted to simplify interpretation of the graph: i.e., a horizontal line was drawn on the figures to mark the $i_{\text {corr }}$ value adopted as the threshold for active corrosion, namely $0.2 \mu \mathrm{A} \mathrm{cm}^{-2}$.

\section{The findings were as follows.}

a) At high relative humidity the addition of chlorides raised the $i_{\text {corr }}$ values in all cases. This rise was apparently somewhat higher in alkali-activated fly ash mortar, where the value grew by a factor of approximately 100.

b) Initially, from the time specimens were cured until they were removed from the moist to the dry laboratory environment, the passive and active state

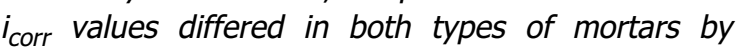
around two orders of magnitude, as in the case of the Portland cement (Figures 3a, b and c).

c) Re-humidification after the drying process led to striking differences between the two types of fly ash mortars, however. The $i_{\text {corr }}$ values in the reinforcement bars embedded in the chloride-free specimens made 

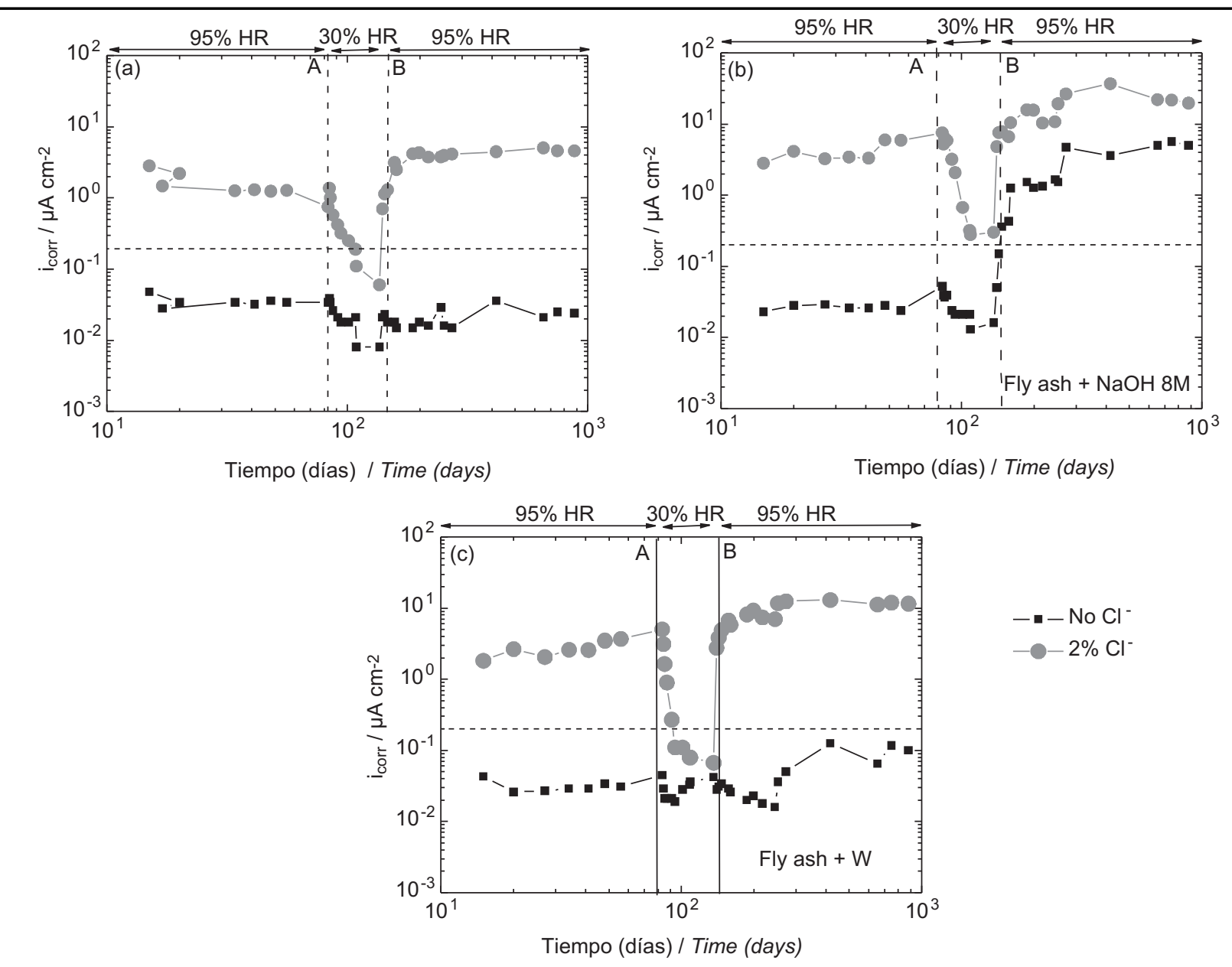

Figura 3. $\mathrm{i}_{\text {corr }}$ en función del tiempo en ausencia y en presencia de $2 \% \mathrm{Cl}^{-}$; (a) Mortero arena /cemento =3/1; (b) mortero arena/ cenizas volantes=2/1 activadas con una solución de $\mathrm{NaOH} 8 \mathrm{M} ;(\mathrm{c})$. mortero arena/ cenizas volantes=2/1 activadas con una solución de NW.

Figure 3. $i_{\text {corr }}$ vs time without and with $2 \%$ Cl; (a) Mortar sand/binder = 3/1; (b) Mortar sand/ fly ash = 2/1 activated with $8 \mathrm{M}-\mathrm{NaOH}$; (c) Mortar sand/ fly ash = 2/1 activated with NW.ash = 2/1 activated with NW.

embebidos en las probetas exentas de cloruros aumentan enormemente, hasta confundirse casi con las estimadas para las probetas con el $2 \% \mathrm{Cl}^{-}$(Figura 3a), mientras que en el activado con NW se sigue conservando el estado pasivo en ausencia de cloruros, manteniéndose las diferencias habituales con el estado activo.

En la Figura 4 (a, b y c) se representan las corrientes de corrosión para las mismas matrices en función de la resistencia eléctrica compensada por el positive feed back del potenciostato al efectuar las medidas de $R_{p}$ (proporcional a la resistividad del mortero), que depende del grado de humectación de la red de poros. Los resultados obtenidos muestran una proporcionalidad inversa, en coordenada logarítmicas, entre las $\mathrm{i}_{\text {corr }}$ de los refuerzos activos y la resistencia compensada por el positive feed back del potenciostato durante las medidas (Figuras 3a, b y c); ello concuerda con el comportamiento ya reconocido para los morteros u hormigones de cemento Pórtland (31-33). with 8-M NaOH-activated mortar rose steeply, to nearly the same levels as estimated for the specimens containing 2\% Cl- (Figure 3a). In the NW-activated mortars, on the contrary, passivity was maintained in the absence of chlorides and the usual differences were observed between the active and passive state values.

Figure $4(a, b$ and $c)$ show the corrosion currents for the same matrices versus the positive feedbackcompensated electrical resistance during the $R_{p}$ (parameter proportional to mortar resistivity) readings; these values depend on the moisture content in the pore network. The findings showed inverse proportionality, in logarithmic coordinates, between the $i_{\text {corr }}$ of the active reinforcing steel and positive feedback compensation during potentiostat readings (Figures $3 a, b$ and $c$ ). This concurs with the behaviour long acknowledged in Portland cement mortars or concretes (31-33). 


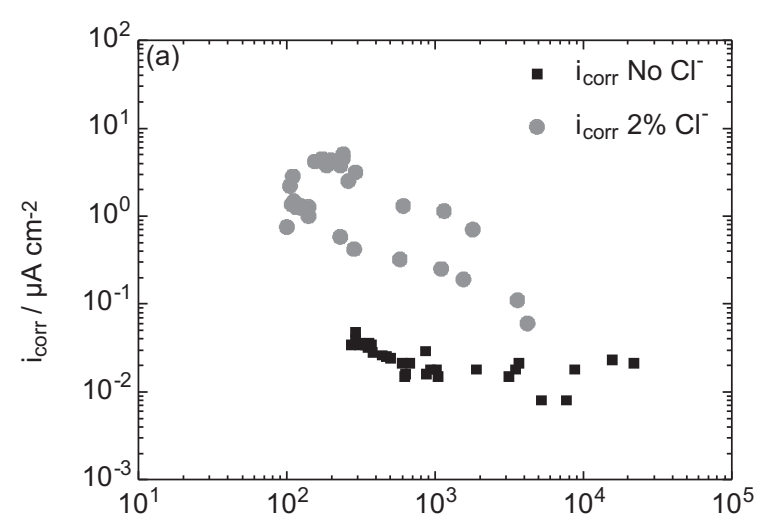

Resistencia compensada/ $/$ / Compesated resistance/ $\Omega$

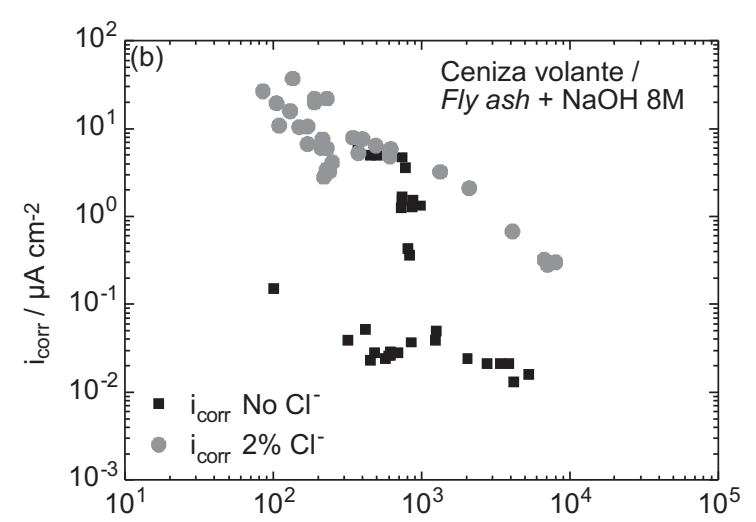

Resistencia compensada/ $/$ / Compesated resistance/ $\Omega$

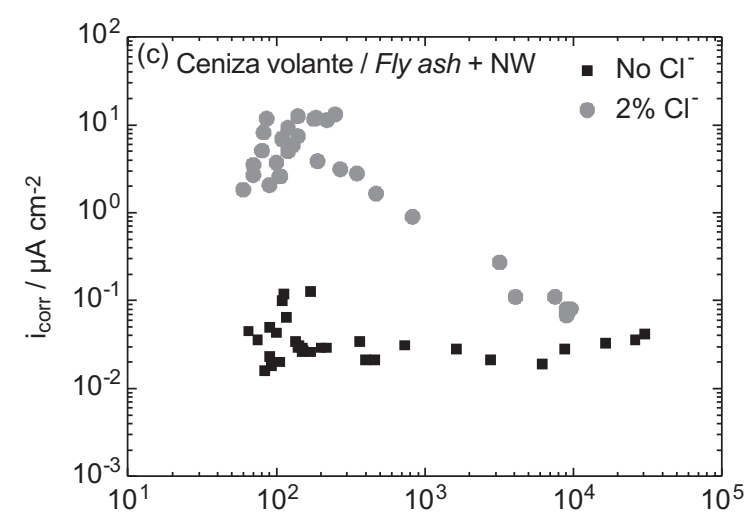

Resistencia compensada/ $\Omega$ / Compesated resistance/ $\Omega$

Figura 4. $\mathrm{i}_{\text {corr }}$ en función de la resistencia compensada por el positive feed back del potenciostato entre los electrodos de trabajo y el contraelectrodo; (a) Mortero arena /cemento $=3 / 1$; (b) mortero arena/cenizas volantes $=2 / 1$ activadas con una solución de $\mathrm{NaOH} 8 \mathrm{M}$; (c). mortero arena/cenizas volantes=2/1 activadas con una solución de NW.

Figure 4. $i_{\text {corr }}$ vs the resistance compensated by positive feedback into the potentiometer during readings;

(a) Mortar sand/binder = 3/1; (b) Mortar sand/fly ash = 2/1 activated with 8M-NaOH; (c) Mortar sand/ fly ash = 2/1 activated with NW.

Se observa que mientras en los morteros de cemento Pórtland y en el de ceniza volante activada con NW las resistencias compensadas por el potenciostato alcanzan valores de $3 \times 10^{4} \Omega$, aproximadamente (Figuras 4 a y $4 c$ ), en el mortero de cenizas volantes activadas con $\mathrm{N}$ no llegan a alcanzarse los $10^{4} \Omega$ (Figura $4 \mathrm{~b}$ ). Esto, como se verá más adelante, podría deberse a que este mortero presenta mayores valores de porosidad lo cual aumenta su permeabilidad.

Es sabido que la porosidad de los materiales influye no sólo en las resistencias mecánicas sino también en su durabilidad ya que una elevada porosidad puede facilitar el ingreso en el material de agentes agresivos como los $\mathrm{Cl}^{-}$. Si bien en este caso el material no ha sido expuesto a un ambiente externo rico en $\mathrm{Cl}$ como en otros trabajos (14-17), sino que directamente se le ha adicionado un elevado porcen-

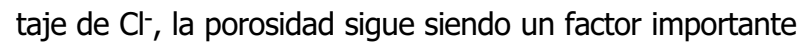
a considerar ya que actúa como medio de movilidad de los mismos. Así en la Figura 5 se presentan los valores de
While in both Portland cement and NW-activated fly ash mortars potentiostat-compensated resistance reached values of approximately $3 \times 10^{4} \Omega$ (Figures $4 a$ and $4 C$ ), in the $N$-activated fly ash mortar it was lower than $10^{4} \Omega$ (Figure 4b). The difference, as discussed below, may have been due to the higher porosity and consequently greater permeability of this third mortar.

Porosity is known to affect not only mechanical strength but durability as well, for high porosity furthers the ingress of aggressive agents such as $\mathrm{Cl}$ into the material. In this case the material was not exposed, as it was in prior studies (14-17), to a chloride-rich external environment, but rather had a high percentage of $\mathrm{Cl}^{-}$ added directly to the mix. Porosity nonetheless played an important role, constituting a mobility medium for the ions. Figure 5 shows the effective porosity values and pore size distribution for Portland cement and activated 
porosidad abierta y distribución de tamaño de poro de los morteros de cemento Pórtland y de los morteros de ceniza volante activada (muestras 1,3 y 5 , respectivamente). El mortero de OPC y de ceniza volante activada con la mezcla NW muestran los menores valores de porosidad (7,6\% y $9,6 \%$, respectivamente), sin embargo, el mortero de ceniza volante activado con $\mathrm{NaOH} 8 \mathrm{M}$ muestra un mayor nivel de porosidad $(\approx 14 \%)$ y también un mayor porcentaje de poros de mayor tamaño entre 10-0,1 $\mu$ m. fly ash mortars (samples 1, 3 and 5, respectively). The OPC mortar and NW-activated fly ash had porosity values of 7.6 and $9.6 \%$, respectively, while the fly ash mortar activated with $8-\mathrm{M} \mathrm{NaOH}$ had a porosity of $\sim 14 \%$, as well as a higher percentage of pores in the $10-0.1 \mu \mathrm{m}$ range.

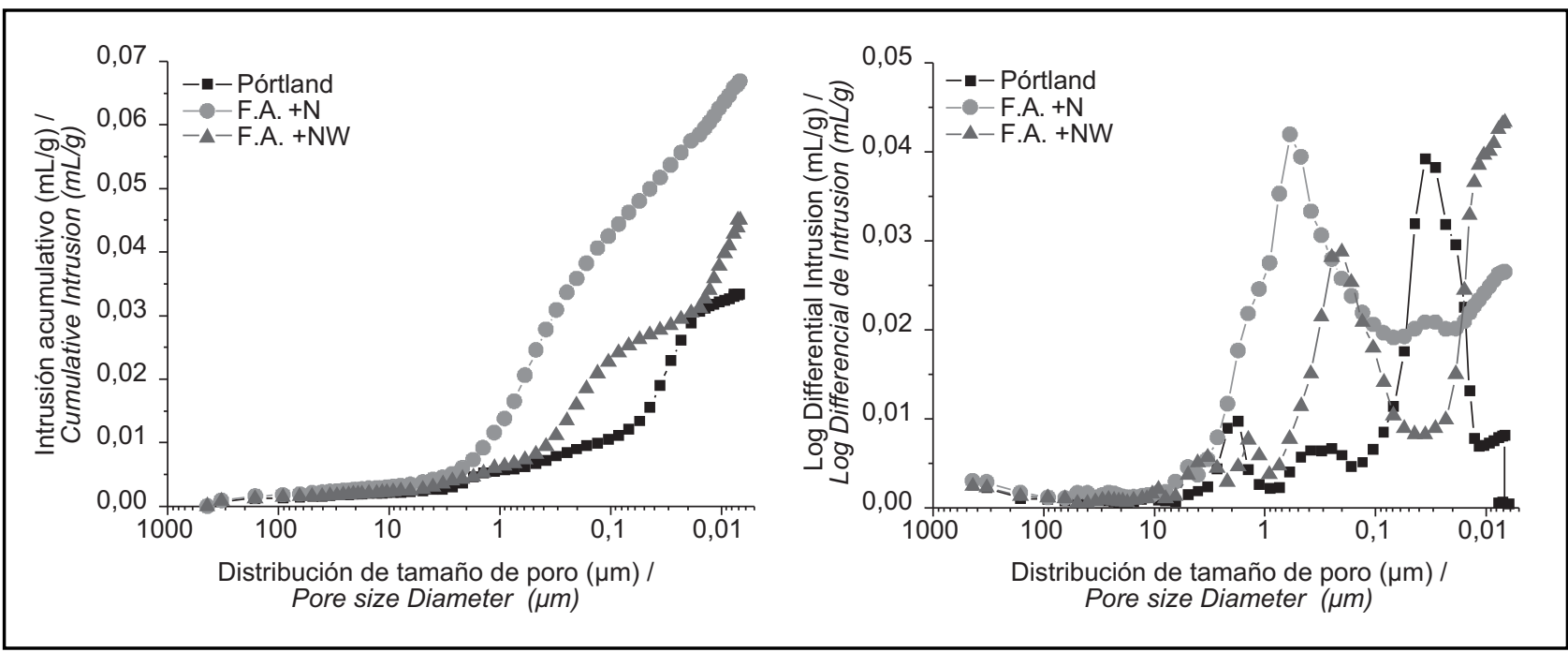

Figura 5. Porosimetría de Intrusión de mercurio (MPI) después de 2,5 años. Figure. 5 Mercury Intrusion porosimetry (MPI) after 2.5 years.

Otro dato importante a destacar es el aspecto físico que presentan las probetas al finalizar los ensayos. En la Figura 6 se observa que las probetas con $\mathrm{Cl}^{-}$muestran de forma evidente que han pasado por un proceso de corrosión ya que la superficie de las probetas presenta microfisuras en la dirección de las armaduras junto a manchas marrones debido a la exudación del producto de corrosión. El mortero de ceniza activada con $\mathrm{NaOH}$ incluso en ausencia de $\mathrm{Cl}^{-}$también muestra la presencia de manchas, lo cual corrobora los datos anteriores que indican que en este caso el acero también ha sufrido corrosión. Este fenómeno puede ser atribuido a los diferentes valores de porosidad abierta y de distribución de tamaño de poro observado entre los morteros de ceniza activados con la disolución N o NW. Si el hormigón es más poroso en caso de producirse corrosión los productos de corrosión difunden más fácilmente hacia la superficie; lo cual tiene ventajas e inconvenientes. Una mayor porosidad facilita una mayor difusión de los productos originados en la corrosión que además pueden precipitar en los espacios libres disponibles. En caso contrario una baja porosidad previene la difusión de los productos de corrosión en el hormigón o mortero adyacente y lo confina en la zona de interfase acero-hormigón lo cual es más peligroso ya que su acumulación origina fisuras, desprendimientos de la pieza con consecuencias potencialmente negativas.
Another important factor was the physical appearance of the specimens at the end of the test. Figure 6 shows that the specimens containing $\mathrm{Cl}^{-}$were visibly corroded, with micro-cracks on the surface in the direction of the reinforcement bars and brown stains attributable to the corrosion products. The $\mathrm{NaOH}$-activated fly ash mortar had stains Even in the absence of $\mathrm{Cl}^{-}$, corroborating the earlier findings to the effect that the steel in these specimens was corroding. This development may be attributed to the differences in the effective porosity values and pore size distribution observed in the $\mathrm{N}$ - and NW-activated fly ash mortars. If corrosion occurs in more porous concrete, the corrosion products rise to the surface more readily. This has advantages and drawbacks. Greater porosity fosters greater dissemination of the corrosion products, which may, moreover, precipitate in any existing free spaces. By contrast, low porosity prevents dissemination into the adjacent mortar or concrete, confining the corrosion products to the steel-concrete interface. This is much more detrimental, for accumulation of these products gives rise to cracks and detachment of whole fragments of material, with potentially adverse consequences. 


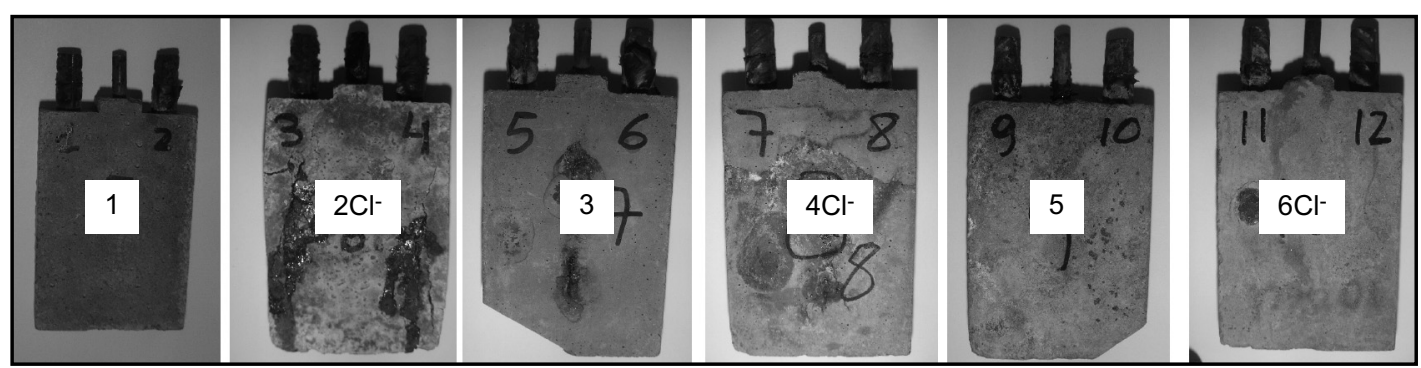

Figura 6. Fotografía de los morteros después de 2,5 años.

Figure 6. Photograph of the mortar specimens after 2.5 years.

Los resultados de este trabajo muestran que, igual que sucede en el caso de las probetas fabricadas con cemento Pórtland, los cloruros ejercen el efecto despasivante sobre la película protectora formada en la interfase acero-mortero $(20,21,34)$.

En ausencia de cloruros, las cenizas volantes activadas también pueden dar lugar a una rápida pasivación de los refuerzos de acero, aunque este hecho se puede ver afectado por el tipo de activador empleado y por las variaciones en las condiciones ambientales. Cambios fuertes en las humedades relativas de la atmósfera (en el grado de humectación de la red de poros de los morteros por tanto), destruyen el estado pasivo en el mortero de ceniza activado con solución de $\mathrm{NaOH} 8 \mathrm{~N}$, mientras que no afecta la estabilidad del estado pasivo en los morteros fabricados con cemento Pórtland, o con cenizas volantes activadas con NW. Resultados similares han sido obtenidos por otros autores cuando estudiaron el comportamiento de las armaduras embebidas en hormigones de escorias activadas alcalinamente (30).

La mayor corrosión observada en el mortero activador con $\mathrm{N}$ se debe asociar a una cierta pérdida de alcalinidad. Si la alcalinidad se mantiene en la fase acuosa se deberían mantener las condiciones de perfecta pasivación y por tanto no aparecer la corrosión. El porqué se pierde la pasivación de estos materiales (especialmente en el caso del material activado con la disolución $\mathrm{N}$ ), puede ser debido a problemas en su ejecución y curado inicial que dan lugar a materiales más porosos, hecho comprobado en trabajos previos (35-37). Ello en parte puede justificar que al pasar de unas condiciones ambientales a otras puede aumenta la velocidad de difusión de $\mathrm{CO}_{2}$, aumentando la carbonatación y descendiendo el $\mathrm{pH}$. Por otro lado, cómo estos materiales apenas tienen $\mathrm{Ca}$, su carbonatación produce $\mathrm{Na}_{2} \mathrm{CO}_{3}$ que es bastante soluble y puede exudar y por tanto es difícil de detectar. Por otro lado, los morteros $\mathrm{N}$, tal y como se muestra en la Figura 1, presentan unos valores de resistencia muy inferiores a los morteros WN, así como una mayor porosidad y mayor tamaño de poros lo cual también puede justificar que el material $\mathrm{N}$ presente un peor desempeño a corrosión.
The present findings showed that, as in the case of Portland cement specimens, chlorides had a depassivating effect on the protective film that forms along the steel-mortar interface $(20,21,34)$.

In the absence of chlorides, activated fly ash may also rapidly passivate reinforcing steel, although this action may be impacted by the type of activator used or variations in environmental conditions. Wide fluctuations in relative humidity (and hence in the moisture content in the pore network) destroyed the passive state in 8-M $\mathrm{NaOH}$-activated fly ash mortar, while they had no effect on passive state stability in Portland cement mortars or NW-activated materials. Similar results were obtained by other authors studying the behaviour of reinforcement bars embedded in alkali-activated slag concrete (30).

The greater corrosion observed in the $\mathrm{N}$-activated mortar must be associated with a certain loss of alkalinity. If alkalinity is maintained in the aqueous phase, the steel should remain perfectly passive and consequently immune to corrosion. The cause of de-passivation in these materials (especially in the $\mathrm{N}$-activated material) may lie in problems arising during initial preparation and curing, as has been shown in prior studies (35-37). Such problems may partially explain the rise in the $\mathrm{CO}_{2}$ diffusion rate with the change in environmental conditions and the ensuing increase in carbonation that lowered the $\mathrm{pH}$. Furthermore, since these materials had a very low Ca content, the product of carbonation was $\mathrm{Na}_{2} \mathrm{CO}_{3}$, a fairly soluble compound difficult to detect because of its bleedability. Lastly, as Figure 1 shows, $N$ mortars had much lower strength values than the NW materials, as well as higher porosity and a larger pore size, all of which contributed to poorer corrosion performance. 


\section{CONCLUSIONES}

- Los resultados obtenidos muestran que los morteros de ceniza volante activada alcalinamente pueden pasivar los refuerzos de acero, si bien la estabilidad del estado pasivo ante cambios en las condiciones ambientales parece mostrar una fuerte dependencia de la disolución activadora empleada.

- En ausencia de cloruros: i) el mortero de ceniza volante activado con la disolución NW presenta $\mathrm{E}_{\text {corr, }}$ $R_{p}$ y $I_{\text {corr }}$ comparables a los observados para el mortero de cemento Pórtland garantizando con ello la permanencia del estado pasivo de los refuerzos, incluso al variar las condiciones ambientales (humedad-secado-humedad); ii) el mortero activado con la disolución $\mathrm{N}$, en ausencia de cloruros y al variar las condiciones ambientales se activa, este comportamiento se asocia con que dicho material, presenta desde el inicio un menor desempeño, es decir, menor resistencia mecánica, mayor porosidad y mayor tamaño de poro. No obstante para poder entender mejor este comportamiento sería importante realizar en próximos trabajos un estudio sobre la naturaleza y la integridad de los productos de hidratación formados en la interfase mortero acero ya que ello juega un importante papel en el control de los fenómenos de pasivación y despasivación del metal.

- En presencia de un $2 \%$ de $\mathrm{Cl}^{-}$en condiciones de humedad, los refuerzos se activan, multiplicándose las velocidades de corrosión del acero por un factor de 100, aproximadamente, en los tres materiales estudiados. Presentando, en general, los morteros de ceniza volante activada alcalinamente un comportamiento muy similar al observado en el mortero fabricado con el cemento Pórtland tradicional.

\section{AGRADECIMIENTOS}

Los autores quieren dar las gracias por su ayuda en la financiación de estas investigaciones al Ministerio de Ciencia e Innovación (proyecto MAT 2006-11705) y a la Agencia Estatal Consejo Superior de Investigaciones Científicas (proyecto Intramural Especial del Programa de Ayudas para la incorporación de personal investigador a las Escalas Científicas del CSIC, REF.: 200960I072). También agradecer a J. García y A. Gil su ayuda en la preparación de los morteros.

\section{CONCLUSIONS}

- The above findings showed that alkali-activated fly ash mortars were able to passivate steel reinforcement, although passive state stability in changing environmental conditions was found to depend heavily on the activating solution used.

- In the absence of chlorides: i) the NW-activated fly ash had $E_{\text {corr }}, R_{p}$ and $I_{\text {corr }}$ values comparable to the findings observed for Portland cement. This ensured the ongoing passivity of the reinforcing steel, even under changing environmental conditions (moist-drymoist); ii) in the absence of chlorides, when exposed to changing environmental conditions, the $\mathrm{N}$ activated mortar was de-passivated. This behaviour was associated with the poorer performance observed in this material from the outset: lower mechanical strength, greater porosity and large pore size. For a fuller understanding of this behaviour, however, future work should focus on the nature and integrity of the hydration products forming at the mortar-steel interface, which play a substantial role in governing metal passivation and de-passivation.

- In the presence of $2 \% \mathrm{Cl}^{-}$and in a moist environment, the steel was activated and the corrosion rate was multiplied by a factor of approximately 100 in all three materials studied. As a rule, the alkali-activated fly ash mortars behaved in much the same way as the traditional Portland cement mortar under these circumstances.

\section{ACKNOWLEDGEMENTS}

This research was funded by the Ministry of Science and Innovation (project MAT 2006-11705) and the Spanish National Research Council (Special Support Programme for Scientific Staff Employment, ref. 200960I072). The authors wish to thank J. García and A. Gil for their assistance in preparing the mortars.

\section{BIBLIOGRAFÍA / BIBLIOGRAPHY}

(1) Bouzoubaâ, N.; Zhang, M. H.; Malhotra, V. M.; Golden, D. M.: "Blended fly ash cement- A review", ACI Materials Journal, 96 (6) (1999), pp. 641-650.

(2) Lukasik, J.; Damtoft, J. S.; Herfort, D.; Sorrentino D.; Gartner E. M.: "Sustainable Development and Climate Change Initiatives". 12th Inter. Cong. On the Chemistry of Cement, Montreal, Canada, 8-13 July 2007 (MPL-1). 
(3) Fernández, A.; Palomo, A.; López-Hombrados, C.: "Some engineering properties of alkali activated fly ash concrete", $A C I$ Materials Journal 103 (2) (2006), pp. 106-112.

(4) Chatterjee, A. K.: "High belite cements - present status and future technological options", Cem. Concr. Res., 26, 8 (1996), pp. 12131225.

(5) Scrivener, K. L.; Cabiron, J. L.; Letourneaux, R.: "High performance concrete based on Calcium Aluminate Cements", Cem. Concr. Res., 29 (1999), pp. 1215-1223. doi:10.1016/S0008-8846(99)00103-9

(6) Sharp, J. H.; Lawrence, C. D.; Yang, R.: "Calcium sulfoaluminate cement - Low energy cements", Ad. Cem. Concr. Res. 11 (1999), pp. 3-14.

(7) Roy, D. M.: "Alkali-activated cements Opportunities and challenges", Cem. Concr. Res., 29 (1999), pp. 249-254. doi:10.1016/S00088846(98)00093-3

(8) Palomo, A.; Fernández-Jiménez, A.; Kovalchuk, G.; Ordóñez, L. M; Naranjo, M. C.: "OPC-Fly Ash Cementitious System: Study Of The Gel Binders Produced During Alkaline Hydration", J. Materials Science, 42 (2007), pp. 2958-2966. doi:10.1007/s10853-006-0585-7

(9) García Lodeiro, I.; Fernández-Jiménez, A.; Palomo, A. and Macphee, D. E.: "Effect of calcium on N-A-S-H cementitious gels", J. American Cerámica Society, 93 (7) (2010), pp 1934-1940. doi: 10.1111/j.1551-2916.2010.03668.x

(10) Palomo, A.; Grutzeck, M. W.; Blanco, M. T.: "Alkali-activated fly ashes. A cement for the future", Cem. Concr. Res., 29 (1999), pp. 1323-1329. doi:10.1016/S0008-8846(98)00243-9

(11) Duxson, P., Fernández-Jiménez, A., Provis, J.L.; Lukey, G.C.; Palomo, A.; van Deventer, J. S. J.: "Geopolymer technology: The current state of the art", J. Materials Science, 42 (2007), pp. 2917-2933 doi:10.1007/s10853-006-0637-z

(12) Fernández-Jiménez, A.; García-Lodeiro, I.; Palomo, A.: "Durability of alkali-activated fly ash cementitious materials", J. Materials Science, 42 (2007), pp. 3055-3065. doi:10.1007/s10853-006-0584-8

(13) Naik, T. R.; Singh, S. S.; Hussain, M. W.: "Permeability of concrete containing large amounts of fly ash", Cem. Concr. Res. 24 (1994), pp. 913-922. doi:10.1016/0008-8846(94)90011-6

(14) Thomas, M.: "Chloride thresholds in marine concrete", Cement Concr. Res, 26 (4) (1996), pp. 513-519. doi:10.1016/0008-8846(96)00035-X

(15) Muralidharan, S.; Saraswathy, V.; Thangavel, K.; Srinivasan, S.: "Competitive role of inhibitive and aggressive ions in the corrosion of steel in concrete", J. Appl. Electrochem., 30 (2000), pp. 1255-1259. doi:10.1023/A:1026570120698

(16) Mangat, P. S.; Molloy, B.T.: "Influence of PFA, slag and micro silica on chloride induced corrosion of reinforcement in concrete", Cem Concr. Res. 21 (1991), pp. 819-834 doi:10.1016/0008-8846(91)90177-J

(17) Saraswathy, V.; Song, H. W.: "Electrochemical Studies on the corrosion performance of steel embedded in activated fly ash blended concrete", Electrochemical Acta 51 (2006), pp. 4601-4611. doi:10.1016/j.electacta.2006.01.005

(18) Bastidas, D. M.; Fernández-Jiménez, A.; Palomo, A.; Gonzalez J. A.: "A study on the passive state stability of steel embedded in activated fly ash mortars", Corrosion Science, 50 (4) (2008), pp. 1058-1065. doi:10.1016/j.corsci.2007.11.016

(19) Miranda, J. M.; Fernández-Jiménez, A.; González, J. A.; Palomo, A.: "Corrosion resistance in activated fly-ash mortars", Cem. Concr. Res., 35 (2005), pp. 1210-1217. doi:10.1016/j.cemconres.2004.07.030

(20) Page, C. L.; Treadaway, K. W. J.; Bamforth, P. B. (eds.): Corrosion of Reinforcement in Concrete, Society of Chemical Industry, published by Elsevier Applied Science, London, 1990.

(21) Slater, J. E.: "Corrosion of Metals in Association with Concrete", ASTM STP 818. Philadelphia, PA 1983.

(22) UNE-EN-196-1:2005 "Métodos de ensayo ce cementos. Parte 1: Determinación de las resistencias mecánicas".

(23) ASTM C876-09 "Standard Test Mehod for Half-cell Potentials of uncoated reinforcing steel in concrete".

(24) Stern, M.; Geary A. L.: "Electrochemical polarization I. A theoretical analysis of the shape of polarization curves", J. Electrochem. Soc., 104 (1957), pp. 56-63. doi:10.1149/1.2428496

(25) Fernández-Jiménez, A.; Palomo, A.: "Factors affecting early compressive strength of alkali activated fly ash (OPC-free) concrete", Mater. Construc., vol., 57, no 287 (2007), pp. 5-20.

(26) Fernández-Jiménez, A.; Palomo, A.: "Composition and Microstructure of alkali activated fly ash mortars. Effect of the activator", Cem. Concr. Res., 35 (2005), pp. 1984-1992. doi:10.1016/j.cemconres.2005.03.003

(27) Criado, M.; Fernández-Jiménez, A.; Palomo, A.; Sobrados, I.; Sanz, J.: "Effect of the SiO2/Na2O ratio on the alkali-activation of fly ash. Part II: 29Si MAS-NMR survey", Microporous and Mesoporous Materials, 109 (2008), pp. 525-534. doi:10.1016/j.micromeso.2007.05.062

(28) Durar Network, Manual de Inspección, Evaluación y diagnostico de corrosión en estructuras de hormigón armado, CYTED programe, Río de Janeiro, 1997.

(29) Andrade, C.; Alonso, M. C.; González, J. A.: "An initial effort to use the corrosion rate measurements for estimation rebar durability", in: N. S. Berke, V. Chaker, D. Whiting (eds.). Corrosion rates of steel in concrete ASTM STP 1065, American Society for Testing and materials, Philadelphia (1990), pp. 29-37.

(30) Aperador, W.; Mejia de Gutiérrez, R.; Bastidas, D. M.: "Steel corrosion behaviour in carbonated álcali-activated slag concrete", Corrosion Science, 51 (2009), pp. 2027-2033. doi:10.1016/j.corsci.2009.05.033

(31) González, J. A.; Andrade, C.: "Effect of carbonation, chlorides and relative ambient humidity on the corrosion of galvanized rebars embedded in concrete", Br. Corros J., 17 (1) (1982), pp. 21-28. 
(32) Alonso, C.; Andrade, C.; González, J. A.: "Relation between resistivity and corrosion rate of reinforcements in carbonated mortar made with several cements types", Cem. Concr. Res., 8 (1988), pp. 687-698. doi:10.1016/0008-8846(88)90091-9

(33) González, J. A.; Miranda, J. M.; Birbilis, N.; Feliu, S.: "Electrochemical techniques for studying corrosion of reinforcement steel: Limitations and advantages", Corrosion, 61 (2005) 3750.

(34) Andrade, C.; González, J. A.: "Quantitative measurements of corrosion rate of reinforcing steels embedded in concrete using polarization resistance mesurements", Werk. Korros., 29 (1978), pp. 515-519. doi:10.1002/maco.19780290804

(35) Fernández-Jiménez, A.; Palomo, A.; Criado, M.: "Alkali activated fly ash binders. A. comparative study between sodium and potassium activators", Mater. Construcc., 56 (281) (2006), pp. 51-65.

(36) Criado; M.; Fernández-Jimenez, A.; Palomo, A.: "Alkali activation of fly ashes. Part 1: Effect of curing conditions on the carbonation of the reaction products", FUEL, 84 (2005), pp. 2048-2054.

(37) Kovalchuk, G.; Fernández-Jiménez, A.; Palomo, A.: "Alkali activated fly ashes. Relationships between mechanical strength gains and initial ash chemistry", Mater. Construc., vol. 58, 291 (2008), pp. 35-52. 